\title{
Effect of some nutrients and amino acids spraying on yield and fruit quality of Manfalouty pomegranate
}

\author{
Mohamed, A.K.A.*, H. A. Abdel-Galil and Naglaa H. Galal \\ Pomology department, Faculty of Agriculture, Assiut University, Assiut 71526, Egypt.
}

\begin{abstract}
Experiment was carried out throughout two successive seasons of 2016 and 2017 on Manfalouty pomegranate trees grown at the Experimental Orchard of Assiut University, Faculty of Agriculture. Thirty six uniform trees ( 9 treatments $\mathrm{x} 4$ replications) were chosen. The spraying treatments were: Micronutrients at the concentration of 2.5 and 5\%, amino acid mixture at 1 and 2\%, and Potassium solution at 1.5 and $3 \%$ and calcium solution at 2.5 and $5 \%$. The obtained results revealed that most of the treatments increased total yield weight. The most effective treatments were micronutrients at $5 \%$; amino acids at $2 \%$ and potassium. All the treatments significantly decreased fruit cracking comparing with the control. The most effective treatments were calcium and potassium spraying. The present data also suggested that spraying with micronutrients and amino acids at $1 \%$ produced the best fruit quality. From the obtained results of the present study it could be recommended that: Spraying micronutrients and amino acids for obtaining the best fruit quality with reasonable yield and healthy fruits. For decreasing the fruit cracking and increase the fruit firmness it could be recommended that to spray the fruit with calcium and potassium.
\end{abstract}

Keywords: Punica granatum; Micronutrients; Amino acids; Fruit cracking; Potassium; Calcium.

\section{Introduction}

Pomegranate (Punica granatum L.) is one of the most important fruit crops in tropical and sub-tropical regions. The pomegranate is associated with the most ancient civilization in the Middle East and it was mentioned in the religion books. The consumption of pomegranate has been associated with beneficial health effects due to the fruits contain high amounts of antioxidants. In Egypt, pomegranate is one of the most important fruit trees cultivated in warm regions such as Assiut governorate, where the climate is characterized by long hot summer and lower air humidity.

*Corresponding author: Aiman K.A. Mohamed aimanmohamed@hotmail.com

Received: June 16, 2020;

Accepted: July 3, 2020;

Published: July 8, 2020.
In recent years, pomegranate is increasingly recognized as attractive fruits that produce valued health beneficial ingredients.

According to the ministry of Agriculture Statistics (2016) the total area devoted for pomegranate was 85415 feddans and fruiting area was 32995 feddans producing about 269070 tons with an average of 8155 ton/feddan. Micronutrients are essentially as important as macronutrients to have better growth, yield and quality. The requirement of micronutrients is only in traces. Micronutrients are involved in all metabolic and cellular functions (Suman et al., 2017). Foliar application of the micronutrients is more effective, economical and quicker way to supply these nutrients and/or to correct their deficiency than soil application. Micronutrients 
are used as individual nutrients or in combination. Investigators (Tehranifar and Tabar, 2009; Mohammed et al., 2011; Sheikh and Manjula, 2012; Hasani et al., 2012; Ahmed et al., 2014; Hamouda et al., 2015 and Maji et $a l ., 2017)$ agreed upon the effectiveness of micronutrients on enhancing pomegranate trees growth, yield and fruit quality.

Amino acids are basic ingredients in the process of protein synthesis. The requirements of amino acids are of a prime important to enhance yield, quality and overall the plant growth and development. Amino acids application use is essential particularly at the critical stages of growth. Exogenous application of amino acids has been reported to improve the growth, yield and quality of pomegranate trees (Khattab et al, 2012; Wassel et al., 2015 and Kamal, 2017).

Potassium $(\mathrm{K})$ is an essential plant nutrient has a great impact on fruit quality. It is involved in many biochemical and physiological process related to plant growth, yield and fruit quality. It is also regulates stomatal for transpiration and photosynthesis. Foliar application of $\mathrm{K}$ was found to be effective on enhancing yield and fruit quality of pomegranate cultivars (Hamouda et al., 2015).

The role of calcium on the rigidity of cell wall is known. It has a role in stabilization of membrane system and the formation of $\mathrm{C}$ pectates which increase the rigidity of middle portion and cell wall of the fruit. It also regulates the mechanism of photosynthesis and protein synthesis (Jackman and Stanley, 1995). It used on pomegranate fruits to reduce fruit cracking and increased yield of healthy fruits (Sheikh and Manjula (2012), Ahmed et al. (2014) and Davarpanah et al. (2018)).

The objective of this study was to assess the influence of the foliar application of micronutrients mixture, amino acids, potassium and calcium on yield, fruit splitting and quality of Manfalouty pomegranate cultivar.

\section{Materials and Methods}

This experiment was executed through two successive seasons of 2016 and 2017 on Manfalouty pomegranate cultivar. Trees were gown at the Experimental Orchard, Faculty of Agriculture, Assiut University. The soil of the experimental orchard is a heavy loam and the trees planted at $5 \times 5 \mathrm{~m}$ apart. They were 35 years old at the beginning of the investigation. Thirty six uniform and healthy trees were selected for this study and arranged in a randomized complete block design. The experiment consisted of 9 treatments, each treatment comprised of 4 trees including the standard treatment (control). Regular agricultural practices were applied to all experimental trees as recommended.

The spraying treatments were as following:

1- Micronutrients mixture at $2.5 \%$.

2- Micronutrients mixture at $5 \%$.

3- Amino acids mixture at $1 \%$.

4- Amino acids mixture at $2 \%$.

5- Potassium at $1.5 \%$

6- Potassium at $3 \%$

7- Calcium at $2.5 \%$

8- Calcium at $5 \%$

9- Control.

The previous spraying compounds were exercised three times. The $1^{\text {st }}$ spraying time was on the $1^{\text {st }}$ week of April and repeated on the $1^{\text {st }}$ week of June and July every season.

The micronutrients were added via a compound contains all the micronutrient in a balanced forms. Also amino acids were as a compound contains all the amino acids. Both potassium and calcium were added as a solutions containing $31.8 \%$ potassium and $12 \%$ calcium. The macronutrients compound was Fetrilon Combi 2 and the amino acids compound was Amino suain which every $100 \mathrm{ml}$ of the solution contains $10 \mathrm{gm}$ free amino acids. A surfactant, super film at $0.1 \%$ was added to the spraying solution. 
At harvest, all the fruits were picked on the $1^{\text {st }}$ 2 weeks of October every season. Fruits per tree were counted and weighed to estimate the total yield weight/tree $(\mathrm{kg})$. As well as cracked fruits were sorted, weighed and counted and then the percentage of cracked fruit relative to the total number and weight of fruit was calculated. The total number and weight of sound fruit per tree was then calculated. After fruit picking, five fruits from each tree were randomly selected and directly transported to the laboratory of fruit section for determining the following physical and chemical properties:

1- Fruit dimensions (length and diameter $\mathrm{cm}$ ).

2- Average fruit weight ( $\mathrm{g}$ ) as well as average fruit rind weight $(\mathrm{g})$ and then calculated the percentage of rind and arils weight relative to the average fruit weight.

3- Fruit firmness $\left(1 \mathrm{~b} / \mathrm{inch}^{2}\right)$ was determined by using the pressure tester.

4- Juice weight of $100 \mathrm{~g}$ arils.

5- Total soluble solids \% was estimated by using the hand refractometer.

6- Total acidity using titration by $\mathrm{NaOH}$ at $0.1 \mathrm{~N}$ and phenolphthalene as an indicator and then expressed as citric acid according to A.O.A.C. (1995).

7- TSS/acid ratio was then calculated.

8- Total and reducing sugars was determined according to A.O.A.C. (1995).

9- Vitamin $C$ was determined according to A.O.A.C. (1995).

The experiment was arranged in a complete randomized block design. Data were tabulated and statistically analyzed according to Snedecor and Cochran (1989). Means were compared using the least significant differences (LSD) values at $5 \%$ level of the probability.

\section{Results and Discussion}

\section{Yield components:}

Data presented in Table (1) suggested that most of the treatments significantly exceeded the control respecting total yield weight $(\mathrm{kg} /$ tree $)$ during the $1^{\text {st }}$ season of study. The most effective treatments during the $1^{\text {st }}$ season of study were spraying with micronutrients at $5 \%$, amino acid mixture at $2 \%$ and then potassium at $1.5 \%$. During the $2^{\text {nd }}$ season of study there were no significant differences between the treatments. However, micronutrients mixture at the concentration of $5 \%$ produced the highest yield weight ( $114.88 \mathrm{~kg} /$ tree), while the control yield was $94.38 \mathrm{~kg} /$ tree.

Table (1) showed the treatments effect on number of sound fruits/tree. During the $1^{\text {st }}$ season of study it was found that spraying with micronutrients at $5 \%$, calcium at $2.5 \%$ and then amino acids at $2 \%$ surpassed the rest of treatments. During the $2^{\text {nd }}$ season of study micronutrients at $5 \%$, potassium at $3 \%$, potassium at $1.5 \%$ and calcium at $5 \%$ recorded the highest number of sound fruits. Respecting the effect of different spraying compounds on weight of sound fruits (kg/tree). Table (1) and demonstrated that, during the $1^{\text {st }}$ season of study it could be found that potassium at $1.5 \%$, amino acids at $2 \%$, micronutrients at $5 \%$ and calcium at $2.5 \%$ produced the highest values. During the $2^{\text {nd }}$ season data presented in such table suggested that micronutrients at $5 \%$, potassium at $3 \%$ and then calcium at $2.5 \%$ exhibited the highest values. The differences between the treatments were significant during both seasons of study.

Data of the present study demonstrated that most of treatments increased the total yield and sound fruits/tree. The current study confirmed the results of the previous studies made by Singh et al. (1990), Bambal et al. (1991), Abdel-Aziz et al. (2001), Sheikh and Manjula (2012), Hasani (2012), Hamouda et al. (2015), Davarpanah et al. (2016) and Maji et al. (2017). They found that foliar application of the micronutrients on pomegranate trees increased yield. Amino acids at $2 \%$ also increased both total yield and sound fruits/tree comparing with 
the control. This finding came on line with that reported by Khattab et al. (2012).

They added mixture of amino acids to pomegranate trees and found that the higher doses of amino acids enhanced yield weight. Also, Wassel et al. (2015) found that, foliar application of amino acids increased yield of Wanderfull pomegranate trees. Kamal et al. (2017) also demonstrated that foliar spraying of amino acids increased yield of Wanderfull pomegranate cultivar. On other fruit trees, e.g., orange and mandarine (Pillitteri et al. (2010); grapes (Khan et al., 2012, Belal et al., 2016 and Ahmed et al. 2017) spraying amino acids increased the total yield. Calcium spraying in the present study also increased yield and sound fruits/tree. In the respect, Sheikh and Manjula (2012) spraying pomegranate trees with calcium increased the yield of healthy fruits/tree. Moreover, Khalil and Aly (2013) found that spraying pomegranate with calcium significantly increased yield/tree. Ahmed et al. (2014) suggested that spraying Manfalouty pomegranate trees with calcium improving yield. On the other side, Davarpanah et al. (2018) pointed out that calcium foliar spraying did not have significant effects on yield components.

Table 1. Effect of spraying compounds on yield components of Manfalouty pomegranate cultivar during 2016 and 2017 seasons.

\begin{tabular}{lcccccc}
\hline \multirow{2}{*}{ Character } & \multicolumn{2}{c}{ Total yield /tree (kg) } & \multicolumn{2}{c}{ No. sound fruits/tree } & \multicolumn{2}{c}{$\begin{array}{c}\text { Weight of sound } \\
\text { fruits/ tree }(\mathrm{kg})\end{array}$} \\
\cline { 2 - 7 } & 2016 & 2017 & 2016 & 2017 & 2016 & 2017 \\
\hline Micronutrients & 85.88 & 97.13 & 223.25 & 244.75 & 81.13 & 90.25 \\
2.5\% & 99.63 & 114.88 & 273.00 & 300.00 & 92.75 & 104.38 \\
Micronutrients 5\% & 92.50 & 104.00 & 215.00 & 258.50 & 88.25 & 97.25 \\
Amino acids 1\% & 104.50 & 97.38 & 258.25 & 245.25 & 97.38 & 88.13 \\
Amino acids 2\% & 103.50 & 101.50 & 246.75 & 261.50 & 98.75 & 98.50 \\
Potassium 1.5\% & 87.50 & 102.88 & 227.50 & 263.75 & 83.13 & 101.25 \\
Potassium 3\% & 96.13 & 104.88 & 262.50 & 259.25 & 92.75 & 100.00 \\
Calcium 2.5\% & 94.25 & 96.50 & 248.00 & 261.50 & 92.00 & 91.00 \\
Calcium 5\% & 77.88 & 94.38 & 213.50 & 245.25 & 70.25 & 78.38 \\
Control & 12.56 & NS & NS & 25.05 & 12.45 & 11.23 \\
\hline L.S.D 5\% & & & & & & \\
\hline
\end{tabular}




\section{Fruit cracking percentage:}

The influence of different spraying compounds on fruit cracking \% was found in Table 2. Data presented in such Table showed that all the treatments significantly exceeded the control respecting cracking fruit weight percentage the beset treatments during the $1^{\text {st }}$ season which reduced this trait were calcium at $5 \%$ followed by calcium at $2.5 \%$ and then potassium at $1.5 \%$ while the control gave the highest value $(10.66 \%)$. During the second season of study the treatments also significantly surpassed the control. Potassium at $3 \%$, potassium at $1.5 \%$ and calcium at $2.5 \%$ gave the best results, while the control produced the highest percentage of fruit cracking weight (20.47).

Concerning cracking fruit number percentage, Table 2 demonstrated that the results took the same line of fruit cracking weight $\%$. Where, calcium at $5 \%$, calcium at $2.5 \%$ and potassium at $1.5 \%$ during the $1^{\text {st }}$ season of study produced the lowest number of fruit cracking. While during the $2^{\text {nd }}$ season, potassium at $2.5 \%$, potassium at $1.5 \%$ and potassium at $3 \%$ exhibited the best results. The control treatments recorded the highest number of fruit cracking during the two studied seasons (15.18 and $23.79 \%$, respectively).

Fruit cracking is a common problem encounters pomegranate in the production regions. The fruit splits vertically or horizontally at any age of it, so the fruits become unfit for marketing. This problem caused to crack over $40 \%$ of fruits in some pomegranate cultivars (Malhotra et al., 1983). Exposure to bright sun and/or heavy watering during fruit development following a period of drought may cause fruit to split prematurely (Singh, 1980). Saad et al. (1988) reported that hot dry weather, heredity, variety, fruit growth and cultural practices are the main factors involved on enhancing fruit cracking of pomegranate. The later waves of fruit set have more tendency to split than the early ones (Mohamed, 2004). The present study suggested that spraying with either potassium or calcium reduced fruit cracking percentage either by weight or number of fruits. The effectiveness of potassium and calcium on decreasing the fruit splitting found in the present study was accordance with those reported by Tebranifar and Tabar (2009), Sheikh and Manjula (2012), Khalil and Aly (2013), Ahmed et al. (2014) and Davarpanah et al. (2018).

Table 2. Effect of spraying compounds on cracking fruits percentage of Manfalouty pomegranate cultivar during 2016 and 2017 seasons.

\begin{tabular}{lcccc}
\hline \multirow{2}{*}{ Character } & \multicolumn{2}{c}{ Cracking fruit weight \% } & \multicolumn{2}{c}{ Cracking fruit number \% } \\
\cline { 2 - 5 } Treatment & 2016 & 2017 & 2016 & 2017 \\
\hline Micronutrients 2.5\% & 5.57 & 7.55 & 6.59 & 9.87 \\
Micronutrients 5\% & 4.80 & 10.01 & 5.96 & 10.95 \\
Amino acids 1\% & 4.91 & 6.86 & 6.00 & 7.77 \\
Amino acids 2\% & 7.52 & 10.55 & 9.16 & 12.37 \\
Potassium 1.5\% & 4.70 & 3.07 & 5.91 & 4.13 \\
Potassium 3\% & 5.64 & 1.34 & 6.29 & 2.16 \\
Calcium 2.5\% & 3.81 & 4.82 & 5.62 & 6.09 \\
Calcium 5\% & 2.72 & 6.07 & 4.91 & 7.36 \\
Control & 10.66 & 20.47 & 15.18 & 23.79 \\
\hline L.S.D 5\% & 2.40 & 2.12 & 1.84 & 2.13 \\
\hline
\end{tabular}




\section{Sound fruit weight (g), peel and arils weight \%:}

Table 3 showed average sound fruit weight $(\mathrm{g})$, peel weight $\%$ and arils weight $\%$ of Manfalouty pomegranate cultivar as affected by spraying compounds. Data presented in such Table suggested that during the $1^{\text {st }}$ season amino acids at $1 \%$ and potassium at $1.5 \%$ recorded the highest values of sound fruit weight (409.75 and 405.50, respectively). During the $2^{\text {nd }}$ season it was found that calcium at $2.5 \%$, potassium at $3 \%$ and potassium at $1.5 \%$ represented the best results. Table 3 and Fig. 7 suggested that amino acids at $1 \%$, potassium at $1.5 \%$ and potassium at $3 \%$ recorded the highest percentage of peel weight during the $1^{\text {st }}$ season. During the second season there were no significant differences between the treatments. However, amino acids at $1 \%$, potassium at $1.5 \%$ and calcium at $5 \%$ gave the highest percentage. However, the control recorded the lowest percentage during the $1^{\text {st }}$ season and micronutrient at $2.5 \%$ in the second one. Table 3 demonstrated that arils weight percentage was the highest in control $(66.50 \%)$ during the $1^{\text {st }}$ season of study followed by amino acids at $2 \%$. During the $2^{\text {nd }}$ season of study there were no significant differences between the treatments.

The present study suggested that most of the treatments increased peel weight percentage and decreased arils weight \%. However, the average weight of sound fruits was increased. Tehranifar and Tabar (2009) suggested that foliar application of micronutrients increased the peel percentage. Obaid and Al-Hadethi (2013) found that foliar spraying of micronutrients gave the highest fruit weight. Same results was found by Ahmed et al. (2014), Hamouda et al. (2015) and Maji et al. (2017).

Table 3. Effect of spraying compounds on sound fruit weight (g), peel and ails weight percentage of Manfalouty pomegranate cultivar during 2016 and 2017 seasons.

\begin{tabular}{lcccccc}
\hline \multirow{2}{*}{$\begin{array}{c}\text { Character } \\
\text { Treatment }\end{array}$} & \multicolumn{2}{c}{$\begin{array}{c}\text { Average sound fruit } \\
\text { weight }(\mathrm{g})\end{array}$} & \multicolumn{2}{c}{ Peel weight $\%$} & \multicolumn{2}{c}{ Arils weight $\%$} \\
\cline { 2 - 7 } & 2016 & 2017 & 2016 & 2017 & 2016 & 2017 \\
\hline Micronutrients 2.5\% & 365.75 & 368.25 & 37.20 & 33.85 & 62.73 & 66.15 \\
Micronutrients 5\% & 341.50 & 350.00 & 38.28 & 36.05 & 61.73 & 63.95 \\
Amino acids 1\% & 409.75 & 375.75 & 41.43 & 39.80 & 58.58 & 60.20 \\
Amino acids 2\% & 379.25 & 359.00 & 34.28 & 34.05 & 65.70 & 65.95 \\
Potassium 1.5\% & 405.50 & 376.00 & 40.68 & 37.03 & 59.33 & 62.98 \\
Potassium 3\% & 366.25 & 383.00 & 38.65 & 35.93 & 61.35 & 64.08 \\
Calcium 2.5\% & 353.75 & 386.00 & 37.73 & 34.65 & 62.28 & 65.35 \\
Calcium 5\% & 377.25 & 348.00 & 37.23 & 36.85 & 62.73 & 63.15 \\
Control & 338.75 & 319.50 & 33.48 & 35.60 & 66.50 & 64.40 \\
\hline L.S.D 5\% & 20.21 & 22.25 & 3.76 & NS & 3.76 & NS \\
\hline
\end{tabular}




\section{Fruit dimensions}

Table 4 showed the effect of various spraying compounds on fruit length $(\mathrm{cm})$, fruit diameter (cm) and length/ diameter ratio (L/D) of Manfalouty pomegranate cultivar during 2016 and 2017 seasons. Data presented in such Table suggested that, during the $1^{\text {st }}$ season of study, amino acids at $1 \%$ and then potassium at $1.5 \%$ and $3 \%$ recorded the highest values of fruit length (L). However, during the $2^{\text {nd }}$ season of study the differences between the treatments were not significant. Concerning the fruit diameter (D), the results showed that, during the $1^{\text {st }}$ season of study amino acids at $1 \%$, potassium at $1.5 \%$ and potassium at $3 \%$ gave the highest values. While in the $2^{\text {nd }}$ season of study, calcium at $2.5 \%$, amino acids at $1 \%$ and then potassium at $1.5 \%$ recorded the highest values. On the other side, there were little differences between the treatments in respect of $\mathrm{L} / \mathrm{D}$ ratio.

The present study suggested that amino acids spraying and then potassium and calcium had significant impacts on fruit length and diameter. The results of the current study concerning the positive effective effect of amino acids on fruit dimensions has confirmed by Khattab et al. (2012) and Wassel et al. (2015). Davarpanah et al. (2017 that potassium as foliar application significantly increased fruit dimensions of pomegranate. The positive effect of calcium spraying on fruit dimensions has been reported by Khalil and Aly (2013), Ahmed et al. (2014), Maji et al. (2017) and Davarpanah et al. (2018).

Table 4. Effect of spraying compounds on fruit dimensions of Manfalouty pomegranate cultivar during 2016 and 2017 seasons.

\begin{tabular}{lcccccc}
\hline \multirow{2}{*}{$\begin{array}{l}\text { Character } \\
\text { Treatment }\end{array}$} & \multicolumn{2}{c}{ Fruit length L. $(\mathrm{cm})$} & \multicolumn{2}{c}{ Fruit diameter D. $(\mathrm{cm})$} & \multicolumn{2}{c}{ L/D Ratio } \\
\cline { 2 - 7 } & 2016 & 2017 & 2016 & 2017 & 2016 & 2017 \\
\hline Micronutrients 2.5\% & 8.28 & 7.85 & 8.53 & 8.45 & 0.98 & 0.93 \\
Micronutrients 5\% & 8.38 & 8.13 & 8.48 & 8.60 & 0.99 & 0.95 \\
Amino acids 1\% & 8.93 & 7.98 & 8.98 & 8.90 & 1.00 & 0.90 \\
Amino acids 2\% & 8.38 & 7.75 & 8.60 & 8.35 & 0.98 & 0.93 \\
Potassium 1.5\% & 8.78 & 8.20 & 8.93 & 8.70 & 0.99 & 0.95 \\
Potassium 3\% & 8.48 & 8.03 & 8.93 & 8.58 & 0.95 & 0.94 \\
Calcium 2.5\% & 8.20 & 8.10 & 8.48 & 8.95 & 0.97 & 0.90 \\
Calcium 5\% & 8.43 & 7.88 & 8.50 & 8.63 & 0.99 & 0.91 \\
Control & 7.95 & 7.88 & 8.55 & 8.38 & 0.93 & 0.94 \\
\hline L.S.D 5\% & 0.42 & NS & 0.29 & 0.34 & NS & 0.03 \\
\hline
\end{tabular}

\section{Fruit firmness and juice weight of $100 \mathrm{~g}$ arils:}

Table 5 showed that the most effective treatments on increasing the frit firmness were potassium at $3 \%$, calcium at $2.5 \%$ and then calcium at $5 \%$ where they recorded the highest values during the $1^{\text {st }}$ season of study. During the $2^{\text {nd }}$ season of study, potassium at $1.5 \%$ followed by calcium at $2.5 \%$ and then calcium at $5 \%$ produced the most firmed fruits.
Data of juice weight of $100 \mathrm{~g}$ arils are presented in Table 5 and Fig. 13. The fruits produced in the $2^{\text {nd }}$ year of study had ore juice comparing with that produced in the $1^{\text {st }}$ season.

During the $1^{\text {st }}$ season of study the control produced the highest juice weight followed by potassium at $1.5 \%$ and then amino acids treatments. While in the $2^{\text {nd }}$ season amino acids 
at $2 \%$, amino acids at $1 \%$ and both potassium treatments recorded the highest values.

The present study suggested that amino acids and potassium increased the juice content only in one season and had no effect in the other season. The positive effect of amino acids on increasing the juice content has been found by Wassel et al. (2015) and Kamal et al. (2017). Tehranifar and Tabar (2009) suggested that foliar application of potassium decreased juice content of pomegranate.

Table 5. Effect of spraying compounds on firmness and juice weight of 100 gram arils of Manfalouty pomegranate cultivar during 2016 and 2017 seasons.

\begin{tabular}{lcccc}
\hline \multirow{2}{*}{ Character } & \multicolumn{2}{c}{ Fruit firmness (Ib/inch2) } & \multicolumn{2}{c}{ Juice weight of 100 gm Arils } \\
\cline { 2 - 5 } Treatment & 2016 & 2017 & 2016 & 2017 \\
\hline Micronutrients 2.5\% & 17.75 & 16.23 & 32.75 & 46.50 \\
Micronutrients 5\% & 11.63 & 16.05 & 28.00 & 52.25 \\
Amino acids 1\% & 18.45 & 16.13 & 35.25 & 55.75 \\
Amino acids 2\% & 14.95 & 15.25 & 35.00 & 60.00 \\
Potassium 1.5\% & 18.48 & 22.33 & 37.00 & 53.50 \\
Potassium 3\% & 19.68 & 17.18 & 34.50 & 53.25 \\
Calcium 2.5\% & 19.60 & 19.50 & 29.00 & 51.75 \\
Calcium 5\% & 19.03 & 17.95 & 34.25 & 45.25 \\
Control & 16.33 & 16.28 & 54.50 & 51.00 \\
\hline L.S.D 5\% & 3.80 & 3.16 & 6.17 & 3.44 \\
\hline
\end{tabular}

\section{Fruit sensory attributes:}

Total soluble solids \% (TSS \%), acidity \% and TSS/acid ratio:

Table 6 showed the treatment impacts on TSS\%, acidity and TSS/acid ratio of Manfalouty pomegranate cultivar during 2016 and 2017 seasons. Data found in such Table and Figure demonstrated that in $1^{\text {st }}$ season calcium at $2.5 \%$, amino acids at $1 \%$ and micronutrients recorded the highest percentage of TSS. During the $2^{\text {nd }}$ season the results were accordance with that of the $1^{\text {st }}$ season where calcium at $2.5 \%$ and micronutrients gave the highest TSS\% although the differences were not significant.

Data presented in such Table suggested that micronutrients at 5\%, amino acids at $1 \%$ and potassium at $3 \%$ exhibited the lowest percentage of acidity in the $1^{\text {st }}$ season. During the $2^{\text {nd }}$ season the differences between were not significant. The highest ratio of TSS/ acidity was found in the treatment of micronutrients at $5 \%$ followed by amino acids at $1 \%$ and then potassium at $3 \%$. During the $2^{\text {nd }}$ season of study micronutrients at $5 \%$ also recorded the highest ratio, followed by potassium at $1.5 \%$ and then calcium at $2.5 \%$.

Sugars content and vitamin $C$ :

Table 7 showed the effect of various treatments on sugars contents and V.C. \% of Manfalouty pomegranate cultivar. During the $1^{\text {st }}$ season of study the highest percentage of total sugars was found in the fruits treated with amino acids at $1 \%$, calcium at $2.5 \%$ and micronutrients at $2.5 \%$, however, the rest of treatments had not significant differences. As well as during the second season of study the differences were not significant. Concerning reducing sugars \%, 
same trend of the total sugars could be observed where the same previous treatments recorded the highest percentage and the differences between the rest of treatments were not significant. Also, during the second season the differences were not significant. Micronutrients were the only significant treatments in the $1^{\text {st }}$ season of study while the rest of treatments and the treatments in the $2^{\text {nd }}$ season were not significant. Respecting vitamin $\mathrm{C} \%$ it could be observed that during the two seasons of study, spraying with micronutrients at $2.5 \%$, micronutrients at 5\% and amino acids at 1 and $2 \%$ recorded the highest percentages of V.C. However, the rest of treatments had not a significant effect during the two studied seasons.

Table 6. Effect of spraying compounds on TSS\%, acidity\% and TSS/acid ratio of Manfalouty pomegranate cultivar during 2016 and 2017 seasons.

\begin{tabular}{lcccccc}
\hline \multirow{2}{*}{ Character } & \multicolumn{2}{c}{ TSS \% } & \multicolumn{2}{c}{ Acidity \% } & \multicolumn{2}{c}{ TSS / acid ratio } \\
\cline { 2 - 7 } Treatment & 2016 & 2017 & 2016 & 2017 & 2016 & 2017 \\
\hline Micronutrients 2.5\% & 16.93 & 14.70 & 1.78 & 1.50 & 9.78 & 10.35 \\
Micronutrients 5\% & 16.85 & 14.05 & 1.20 & 1.00 & 14.18 & 14.05 \\
Amino acids 1\% & 17.52 & 13.10 & 1.30 & 1.38 & 13.58 & 10.08 \\
Amino acids 2\% & 16.20 & 13.90 & 1.58 & 1.98 & 10.75 & 7.28 \\
Potassium 1.5\% & 16.37 & 13.55 & 1.88 & 1.25 & 8.75 & 11.60 \\
Potassium 3\% & 16.27 & 13.85 & 1.48 & 1.45 & 11.23 & 9.98 \\
Calcium 2.5\% & 18.07 & 14.25 & 1.85 & 1.38 & 9.95 & 11.33 \\
Calcium 5\% & 16.52 & 13.75 & 1.70 & 1.40 & 9.90 & 10.55 \\
Control & 15.33 & 13.68 & 1.78 & 1.68 & 8.73 & 8.23 \\
\hline L.S.D 5\% & 1.33 & NS & 0.37 & NS & 2.66 & 3.62 \\
\hline
\end{tabular}

Table 7. Effect of spraying compounds on the percentages of sugar and Vitamin C of Manfalouty pomegranate cultivar during 2016 and 2017 seasons.

\begin{tabular}{lcccccccc}
\hline \multirow{2}{*}{$\begin{array}{c}\text { Character } \\
\text { Treatment }\end{array}$} & \multicolumn{2}{c}{ Total sugars \% } & \multicolumn{2}{c}{ Reducing sugars \% } & \multicolumn{2}{c}{ Non-Reducing sugars \% } & \multicolumn{2}{c}{ Vitamin } \\
\cline { 2 - 10 } & 2016 & 2017 & 2016 & 2017 & 2016 & 2017 & \\
\hline Micronutrients 2.5\% & 15.84 & 11.79 & 14.40 & 10.98 & 1.44 & 0.81 & 1.63 & 1.13 \\
Micronutrients 5\% & 15.19 & 11.03 & 13.90 & 9.97 & 1.29 & 1.05 & 1.40 & 0.90 \\
Amino acids 1\% & 16.33 & 11.00 & 15.10 & 9.79 & 1.23 & 1.21 & 1.23 & 0.73 \\
Amino acids 2\% & 13.86 & 11.01 & 12.69 & 9.98 & 1.17 & 1.04 & 1.23 & 0.73 \\
Potassium 1.5\% & 14.54 & 10.78 & 13.46 & 9.82 & 1.08 & 0.96 & 1.08 & 0.58 \\
Potassium 3\% & 14.15 & 11.24 & 13.04 & 10.20 & 1.12 & 1.04 & 1.03 & 0.53 \\
Calcium 2.5\% & 16.16 & 11.14 & 15.00 & 10.04 & 1.17 & 1.10 & 1.13 & 0.63 \\
Calcium 5\% & 14.54 & 11.00 & 13.39 & 9.87 & 1.15 & 1.13 & 1.08 & 0.58 \\
Control & 13.54 & 11.26 & 12.48 & 10.21 & 1.06 & 1.05 & 1.00 & 0.50 \\
\hline L.S.D 5\% & 1.53 & $\mathrm{NS}$ & 1.52 & $\mathrm{NS}$ & 0.19 & $\mathrm{NS}$ & 0.22 & 0.22 \\
\hline
\end{tabular}


The present study revealed that, the most effective treatments for improving fruit sensory attributes were spraying with micronutrients followed by amino acids. The effectiveness of micronutrients spraying on fruit quality of pomegranate has been confirmed by many investigators. Micronutrients are essentially as important as macronutrients to have better growth, yield and quality. The requirements of them is only in traces. These nutrients are involved in all metabolic and cellular functions (Suman et al., 2017).

Investigators, Bambal et al., 1991; Balakrishanan et al., 1996; Tehranifar and Tabar, 2009; Khorsandi et al., 2009; Hasani et al., 2012; Khalil and Ali, 2013; Ahmed et al., 2014; Hamouda et al., 2016 and Maji et al. 2017, agreed upon the effectiveness of micronutrients spraying on improving fruit quality of pomegranates.

On the other side, amino acids are basic ingredients in the process of protein synthesis. The importance of amino acids is required for enhancing yield, fruit quality and overall the tree growth and development. Exogenous application of amino acids has been reported by Khattab and Shaban, 2012; Wassel et al., 2015 and Kamal, 2017 to improve the fruit quality of pomegranate. The later came on line with that reported in the current study. Potassium $(\mathrm{K})$ is an essential nutrient and has a great effect on fruit quality. Foliar application of $\mathrm{K}$ was found to be effective on improving fruit quality of pomegranate cultivars (Hamouda et al., 2015).

\section{Conclusion:}

From the obtained results of the present study it could be recommended that:

1. Spraying micronutrients and amino acids for obtaining the best fruit quality with reasonable yield and healthy fruits.
2. For decreasing the fruit cracking and increase the fruit firmness it could be recommended that to spray the fruit with calcium and potassium.

\section{References}

A.O.A.C. (1995) Association of official Agricultural Chemists, Official methods of analysis, $16^{\text {th }}$ Ed., Washington, DC, USA.

Abdel-Aziz, F.F., Ahmed, F.F., and Morsy, M.H. (2001) 'Relation of potassium, calcium and boron with productive and fruit cracking of Manfalouty pomegranate trees', The Fifth Arabian Hort. Conf. Ismailia, Egypt, pp. 91-99.

Ahmed, F.F., Abdealaal, A.H.M., El-Masry, S.M.A., and Ahmed, A.H.R. (2017) 'Effect of Humic and Flavic acids, Em and Amino Acids on Berries Colouration, Yield and Quality of Flame Seedless Grapes', Assiut J. Agric. Sci., 48(2), pp. 88-103.

Ahmed, F.F., Mohamed M.M., Abou ElKhashab, A.M.A., Aeed, S.H.A. (2014) ' Controlling Fruit Splitting and Improving Productivity of Manfalouty Pomegranate Trees by Using Salicylic Acid and Some Nutrients', World Rural Observations, 6 (1), pp. 87-93.

Balakrishanan, K., Venkatesan, K., and Samband-Ammurthi, S. (1996) 'Effect of foliar application of $\mathrm{Zn}, \mathrm{Fe}, \mathrm{Mn}$ and $\mathrm{B}$ on yield and fruit quality of pomegranate (Punica granatum L.) cv. Gamesh', Orissa, Ournal. Hort. 24 (1-2), pp. 33-35.

Bambal, S.B., Wavhal, K.N., and Nasalkar, S.D. (1991) 'Effect of foliar application of micro-nutrients on fruit quality and yield of pomegranate (Punica granatum L.) cv. Ganesh', Maharashtra, J. Hort. 5 (2), pp. 32-36.

Belal, B.E.A., El-Kenawy, M.A., and Uwakiem, M.K. (2016) 'Foliar application of some amino acids and vitamins to improve growth, physical and chemical properties of Flame Seedless grapevines', Egypt J. Hort. 43 (1), pp. 123-136. Doi: 10.21608/ejoh.2016.2831 
Davarpanah, S., Tehranifar, A., Davarynejad, G., Abadía, J., and Khorasani, R. (2016) ' Effects of foliar applications of zinc and boron nano-fertilizers on pomegranate (Punica granatum cv. Ardestani) fruit yield and quality', Scientia Horticulturae, 210, pp.57-64. doi: 10.1016/j.scienta.2016.07.003

Davarpanah, S., Askari, M.A., Mes Babalar M. Z., and Aghayeh, R.N.M. (2017)'Effect of Foliar Application of Phosphorus, Potassium and Iron on Physical and Chemical Properties of Pomegranate Fruit', Jordan Journal of Agricultural Sciences, 13(3), pp. 693-706.

Davarpanaha, S., Tehranifara, A., Abadíab, J., Valb, J., Davarynejada, G., Aranc, M., and Khorassani, R. (2018) 'Foliar calcium fertilization reduces fruit cracking in pomegranate (Punica granatum cv. Ardestani) ', Scientia Horticulturae, 230, pp.86-91.

doi: 10.1016/j.scienta.2017.11.023

Hamouda, H.A., Abdel Motty, E.Z., and Zahran, N.G. (2015) 'Nutritional Status and Improving Fruit Quality by Potassium, Magnesium and Manganese Foliar Application in Pomegranate Shrubs', International Journal of ChemTech Research, 8(6), pp. 858-867.

Hamouda, H.A., Khalifa, R.Kh.M., ElDahshouri, M.F., and Zahran, N.G. (2016) ' Yield, fruit quality and nutrients content of pomegranate leaves and fruit as influenced by iron, manganese and zinc foliar spray', International Journal of PharmTech Research, 9 (3), pp. 46-57.

Hasani, M., Zamani, Z., Savaghebi, G., and Fatahi, R. (2012) 'Effects of zinc and manganese as foliar spray on pomegranate yield, fruit quality and leaf minerals', Journal of Soil Science and Plant Nutrition, 12 (3), pp. 471-480. doi: 10.4067/S0718-95162012005000009

Kamal, H.M., Elisa, M.A., and Mohammed, A. A. (2017) 'Effect of some mineral compounds on yield and fruit quality of pomegranate', Bioscience Research, 14(4), pp. 1197-1203.

Khalil, H.A., and Aly, H.S.H. (2013) 'Cracking and Fruit Quality of Pomegranate (Punica granatum L.) As Affected by Pre-Harvest Sprays of Some Growth Regulators and Mineral Nutrients', Journal of Horticultural Science \& Ornamental Plants, 5 (2), pp. 71-76.

Khan, A.S., Ahmed, B., Jaskani, M.J., Ahmed, R., and Malik, A.U. (2012). Foliar application of mixture of amino acids and seaweed (Ascophylum nodosum) extract improve growth and physico-chemical properties of grapes', Int. J. Agric. Biol. 14 (3), pp. 385-388.

Khattab, M.M., Shaban, A.E., El-Shrief, A.H., and Mohamed, A.S. (2012) 'Effect of Humic Acid and Amino Acids on Pomegranate Trees under Deficit Irrigation. I: Growth, Flowering and Fruiting', Journal of Horticultural Science \& Ornamental Plants, 4 (3), pp. 253-259.

Khorsand, F., Yazdi, F.A., and Vazifehshenas, M.R. (2009) 'Foliar Zinc Fertilization Improves Marketable Fruit Yield and Quality Attributes of Pomegranate', International Journal of Agriculture \& Biology, 11(6), pp. 766-770.

Maji, S., Yadav, A., and Meena, K.R. (2017) 'Effect of calcium and boron on growth, yield and quality of pomegranate (Punica granatum L.)', International Journal of Plant Sciences, 12 (2), pp.108-113. doi: 10.15740/HAS/IJPS/12.2/108-113

Malhotra, V.K., Khajuria, H.N., and Jawanda, J.S. (1983) 'Studies on physico-chemical characteristics of pomegranate cultivars. 1- Physical characteristics ', Punjab Hort. J. 23(3/4), pp. 153-157. (C.F. Hort. Abst. 54 (8), pp. 9577, 1984).

Masoud, A.A.B., Radwan, E.M.A., and AbouZaid, E.A.A. (2018) 'Effect of some Micronutrients, Silicon and $\mathrm{GA}_{3}$ Spraying on Yield and Fruit Quality of Pomegranate', Assiut J. Agric. Sci., 49(3), pp. 97-106. doi:10.21608/ajas.2018.18688 
Mohamed, A.K.A. (2004) 'Effect of gibberellic acid $\left(\mathrm{GA}_{3}\right)$ and benzyladinine $(\mathrm{BA})$ on splitting and quality of Manfalouty pomegranate fruits', Assiut J. Agric. Sci. 35 (3), pp. 11-21.

Obaid, E.A., and Al-Hadethi, M.E.A. (2013) 'Effect of foliar application with manganese and zinc on pomegranate growth, yield and fruit quality', Journal of Horticultural Science \& Ornamental Plants, 5 (1), pp. 41-45.

Pillitteri, L.J., Bertling, I., Khuong, T., Chao, C.T., and Lovatt, C.J. (2010) 'FoliarApplied Tryptophan Increases Total Yield and Fruit size of Navel Orange and Clementine Mandarin', Acta. Hort., 884, pp. 729-736. doi: 10.17660/ActaHortic.2010.884.99

Saad, F.A., Shaheen, M.A., and Tawfik, H.A. (1988). 'Anatomical study of cracking in pomegranate fruit', Alex. J. Agric. Res. 33 (1), pp. 155-166.

Sheikh, M. K., and Manjula, N. (2012) 'Effect of chemicals on control of fruit cracking in pomegranate (Punica granatum L.) var. Ganesh', Options Méditerranéennes, A, II International Symposium on the Pomegranate, 103, pp. 133-135.

Singh, A. (1980) 'Fruit physiology and production', Kalyani Publishers, New Delhi, pp. 383-385.

Singh, R.P., Sharma, Y.P., and Awasthi, R.P. (1990) 'Influence of different cultural practices on premature fruit cracking of pomegranate', Progressive Hort. 22(1-3), pp. 92-96.

Snedecor, G.W., and Cochran, W.G. (1989). Statistical Methods, $8^{\text {th }}$ Ed., Iowa State Uni. Ames USA.

Suman, M., Sangma, P.D., and Singh, D. (2017) 'Role of Micronutrients ( $\mathrm{Fe}, \mathrm{Zn}, \mathrm{B}, \mathrm{Cu}$, $\mathrm{Mg}, \mathrm{Mn}$ and Mo) in Fruit Crops', Int. J. Curr. Microbiol. App. Sci., 6(6), pp. 32403250. doi:10.20546/ijcmas.2017.606.382

Tehranifar., A. and Tabar, S.M. (2009): Foliar Application of Potassium and Boron during Pomegranate (Punica granatum) Fruit Development Can Inprove Fruit Quality', Hort. Environ. Biotechnol., 50(3), pp. 1-6.

Wassel, A.H.M., Gobara A.A., Ibrahiem, H.I.M., and Shaaban, M.M. (2015) 'Response of Wonderful Pomegranate trees to foliar application of Amino Acids, Vitamins B and Silicon', World Rural Observations, 7(3), pp. 91-95. 